\title{
GROUNDWATER PROSPECTING OF BODO, GOKANA LOCAL GOVERNMENT AREA OF RIVERS STATE USING ELECTRICAL RESISTIVITY METHOD
}

\section{RASAQ BELLO, KAZEEM O. RAUFF AND EFEDE J. OSAKPOLOR}

(Received 20 May 2016; Revision Accepted 28 July 2016)

\begin{abstract}
Groundwater is the water found underground in the cracks and spaces of rock materials called Aquifer. The primary source of ground water is rain and snow that falls into the ground. In order to determine the layers and depth of aquifer, electrical resistivity method was used to investigate the availability of groundwater in the community. The instrument used in this survey is ABEM SAS 300 Terrameter, cables, hammer, electrode and measuring tape. The result of the survey showed that the depth of the aq.uifer at two different locations in the community varies significantly, the aquifer depth ranges from $30 \mathrm{~m}$ to $60 \mathrm{~m}$. It was noted that the thickness of the different layers in the area varied also with location one (1) having an average thickness of $14.32 \mathrm{~m}$ and location two (2) with an average thickness of $10.00 \mathrm{~m}$. Both locations have five layers with the highest resistivity values of $296.10 \mathrm{~m}$ and $248.60 \mathrm{~m}$ respectively. The result shows that, the depth of the aquifer in location 2 which is very close to oil spill site is shallow compared to that of location 1 which is a far more distance to location 2, therefore the groundwater in the second location will be contaminated overtime.
\end{abstract}

KEYWORDS: Groundwater, Aquifer, Electrical Resistivity, Vertical Electrical Sounding (Ves).

\section{INTRODUCTION}

Water as one of the most important natural resources occurs both as surface water and groundwater. It is vital for all life on the earth. Developments of our society are dependent on the availability and use of adequate water. This precious resource is sometimes scarce, sometimes abundant but unevenly distributed, both in space and time. Groundwater represents the second most abundantly available freshwater resources and constitutes about $30 \%$ of fresh water resources of the globe. The origin of groundwater is the water cycle as precipitation is followed by percolation and surface runoffs which recharge acquifers beneath the surface. Ground water may also be recharged natural surface water bodies and artificial sources due to action of man.

Ground water is very useful to humans other living organisms and therefore its utility in nature is enormous. Some of the uses are irrigation, domestic and industrial uses. Groundwater is the water found underground in the cracks and spaces of rock materials called aquifer. An aquifer is a body of saturated rock in which groundwater is stored and transmitted easily. Aquifers may occur at various depths, those closer to the surface are not only more likely to be used for water supply and irrigation, but are also more likely to be topped up by the local rainfall. An Aquifer that is overlain on a low permeable, confining layer often made up of clay is known as Confined Aquifer. The confining layer may offer some protection from surface contamination.
While an Aquifer whose upper surface is open to the atmosphere (water table) through permeable materials is refer to as an Unconfined Aquifer, this Aquifer is most prone to contamination. Groundwater contamination occurs when manmade product such as gasoline, oil, road salts and chemicals gets into the groundwater and causes it to become unsafe and unfit for human. Drinking of contaminated groundwater can have serious health effects; diseases such as hepatitis and dysentery may be caused by contamination from septic tank waste, poisoning may be caused by toxins that have leached into well water supplies.

In order to identify aquiferous layers, determine their depths, and evaluate the water quality, the electrical resistivity method, of geophysical exploration was employed. An evaluation of the state of the groundwater in Bodo community, Gokana L.G.A of Rivers State is considered pertinent, considering that the primary sources of domestic water in the community are surface water bodies such as streams and shallow wells which are very prone to contamination, coupled the high level of environmental pollution caused by Oil spills in the area. The long overdue and urgent need for alternative domestic water sources (possibly from confined aquifers) for the inhabitants of the community is the motivation for this work.

\section{Study Location}

This study was carried out in Bodo, a community in Gokhana local government area of Rivers State, which is situated within the Niger Delta region of Nigeria.

Rasaq Bello, Department of Physics, University of Port Harcourt, Port Harcourt, Nigeria

Kazeem O. Rauff, Department of Physics, Federal University, Kashere, Nigeria

Efede J. Osakpolor, Department of Physics, University of Port Harcourt, Port Harcourt, Nigeria 
Figure 1 shows the map of the study location while figure 2 shows an oil spill site from the study area. The region is known to be made up of three sedimentary units with approximate average thickness of about 12 $\mathrm{km}$. The topmost Benin Formation made up mainly of continental sands with some clay intercalations has been identified to house most of the regions aquifers. Located in the mangrove forests, the area enjoys a substantial amount of rainfall, which ensures recharging of ground water bodies and leaving the ground surface very moist to waterlogged for most of the year.

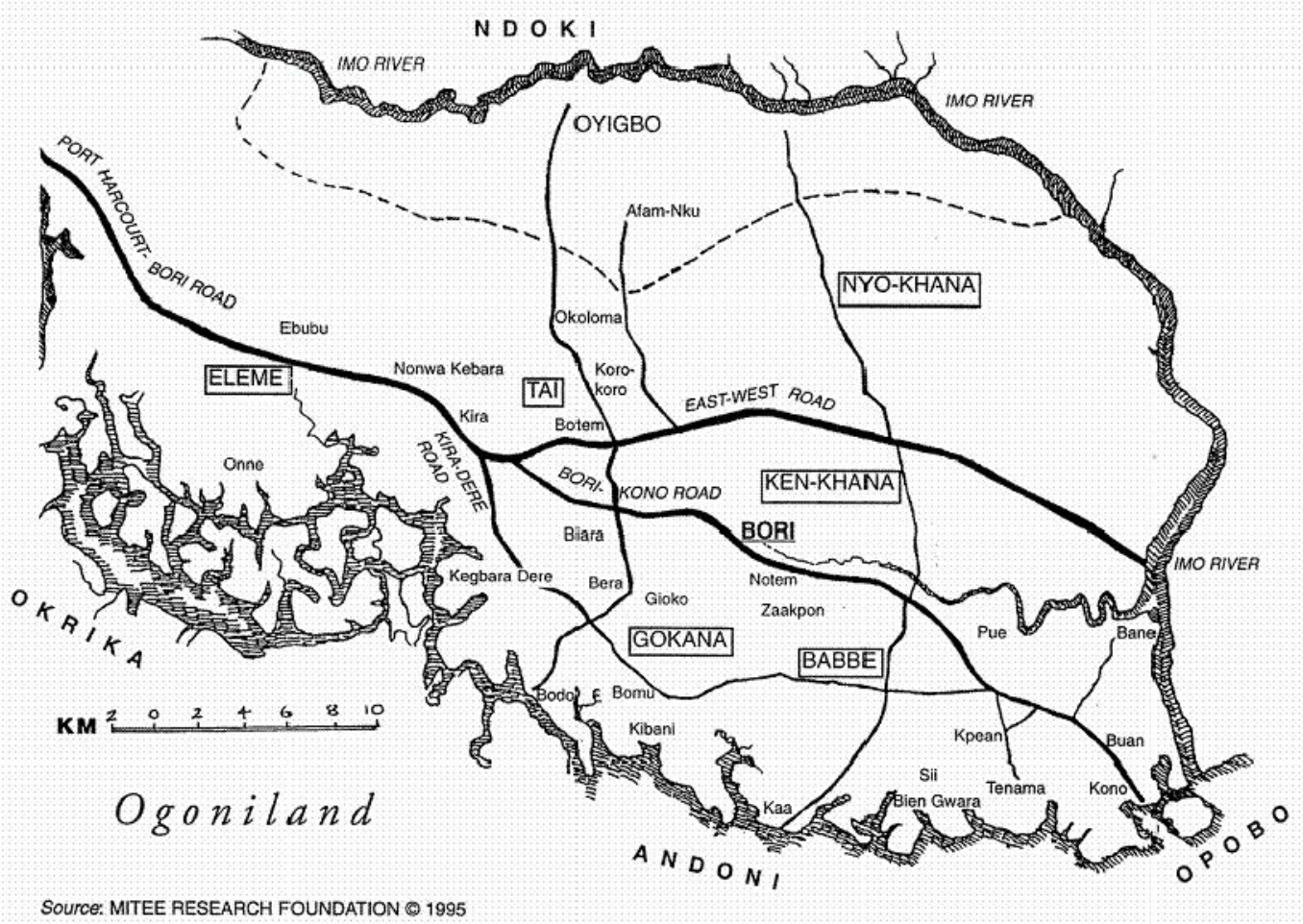

Figure 1: Map of the Study Area

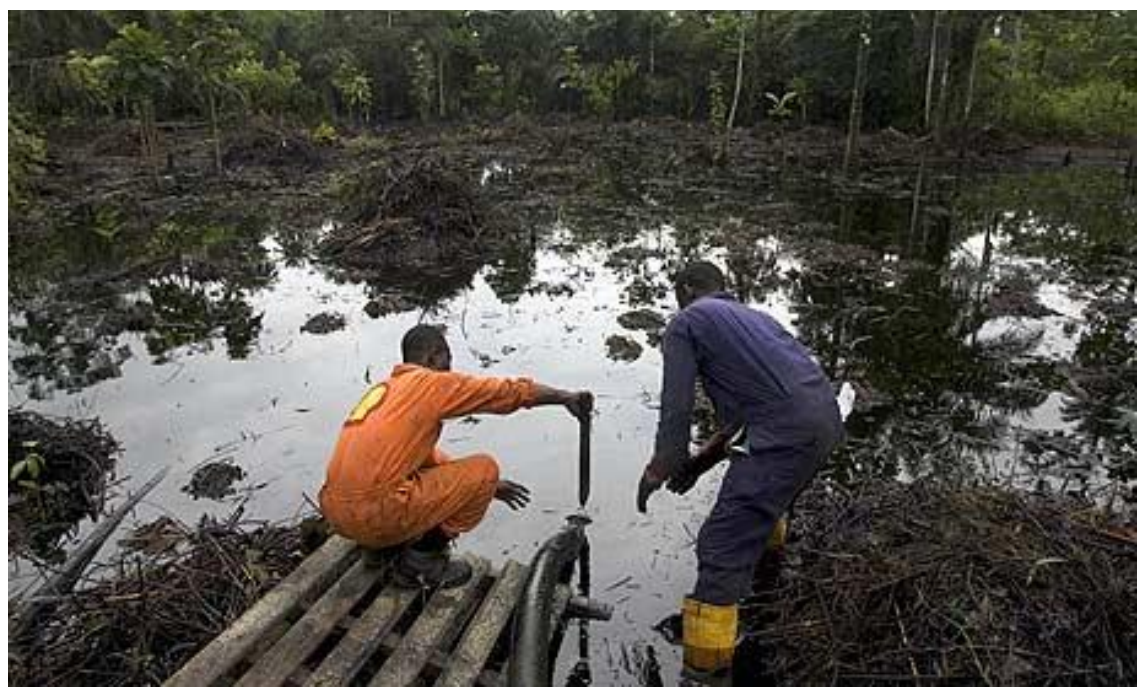

Figure 2: Oil Spill Site in the Study Area (Bodo Community)

\section{$2.0 \quad$ Literature Review}

The history of oil exploration and production in to date has become seemingly intractable in terms of its resolution and future direction.

According to UNEP (2011) report on the 
the Federal Government of Nigeria, significant numbers of locations in Ogoniland are exposed to serious health and environmental threats from contaminated drinking water to concerns over the viability and productivity of ecosystems. In addition that pollution has perhaps gone further and penetrated deeper than many may have previously supposed.

The report concludes that pollution of soil by petroleum hydrocarbons in Ogoniland is extensive in land areas, sediments and swampland. Most of the contamination is from crude oil although contamination by refined product was found at three locations.

The assessment found there is no continuous clay layer across Ogoniland, exposing the groundwater in Ogoniland (and beyond) to hydrocarbons spilled on the surface. In 49 cases,

UNEP observed hydrocarbons in soil at depths of at least $5 \mathrm{~m}$. This finding has major implications for the type of remediation required.

Electrical resistivity survey (vertical electrical sounding) which has wide applications in environmental and engineering works has evolved over several decades (Reynolds, 1997; Chambers et al., 2006). It has been used to image targets with dimensions from millimeter scale to kilometer scale (Storz et al., 2000).

Robin et, al., (1996) linked resistivity variation with the structure of the pedological materials, identifying that high and low resistivity values were related to macro-mesoporosity respectively. This enabled the study of the crack openings at the centimetric scale by Samouelian et al., (2003).

\subsection{METHODOLOGY}

The vertical electrical sounding was used to determine the electrical resistivities and depths of the subsurface layers. The Schlumberger array of electrical resistivity method was applied because of its relatively low cost of field operation, reduced logistics and reliability on application to formation and groundwater investigations (Okolie et al., 2010)

The resistivities of the different layers were measured using the terrameter which is capable of sending current into the earth subsurface through a pair of conducting electrodes, automatically computing and displaying the apparent resistivity of the subsurface structure under investigation.

In this study, however, the terrameter was connected to four linearly arranged electrodes which were hammered into the earth at appropriate intervals to ensure that current electrodes separation is much greater than the potential electrodes spacing as required in the Schlumberger array (Figure 4) Okolie et al. (2008). This array was used to ensure deep penetration as the current electrodes separation increases geometrically for each successive reading with respect to the potential electrode spacing and for logistics of limited manpower and time management since the potential electrode are seldom moved.

The electrodes array was laid along each transect and readings were taken at two hundred meters (i.e. $100 \mathrm{~m}$ back and $100 \mathrm{~m}$ forward). Series of readings were taken with different electrode spacing and with the Centre point of array being kept constant. Figure 3 shows the equipment used for this work. The procedure involves expanding the current electrodes $A B$, while keeping the potential electrodes $\mathrm{MN}$ relatively fixed and the readings of the potentials taken as described in Figure 4. The apparent resistivity measured with the smallest spacing was virtually the resistivity of the surface layer. As the spacing is increased, progressively deeper layers influenced the apparent resistivity. The current passing through the earth between two potential electrodes and the resultant potential differences were computed to give resistivity of a layer at a surface in digital form by the Terrameter SAS 300 (Dobrine, 1960).

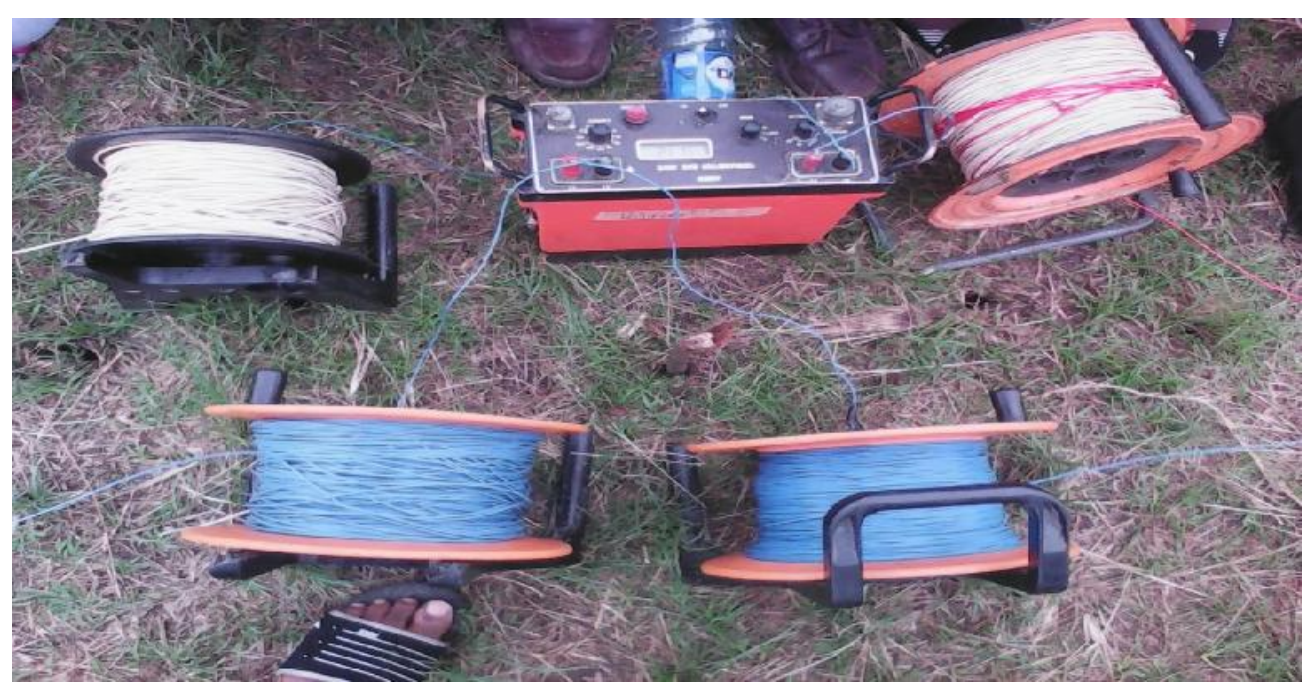

Figure 3: Geophysical field equipment 


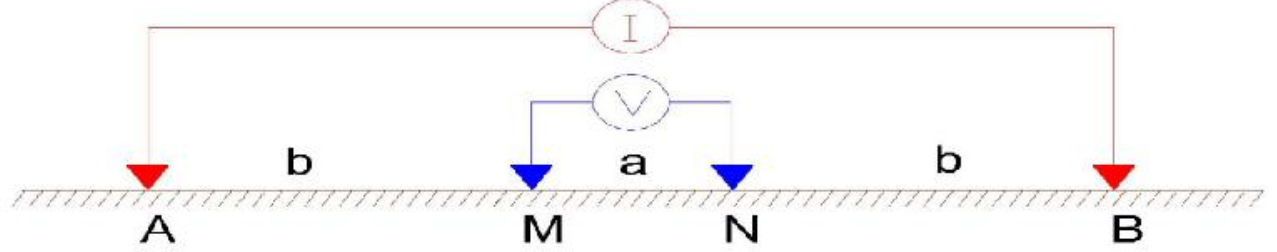

Figure 4: Schlumberger electrode array

From figure 4 , the distance between the current electrodes $(A B) / 2=s$, and the distance between the potential electrodes $(\mathrm{MN}) / 2=\mathrm{a}$. Therefore the equation for apparent resistivity becomes;

$$
\rho_{a}=\pi\left[\frac{S^{2}}{a}-\frac{a}{4}\right] \frac{V}{I}=\pi a\left[\left(\frac{S}{a}\right)^{2}-\frac{1}{4}\right] \frac{V}{I}
$$

\subsection{RESULTS AND DISCUSSIONS}

The VES field data and computed data are shown in Table 1 while the field curves and interpreted models are presented in terms of number of layers, resistivity, depth and thickness in table 2. Figures 5 and 6 give the interpreted curve, model of field data from sites 1 and 2 which shows the number of layers, the resistivity, and depth and the thickness of the different layers, while figure 7 shows the hydrogeoelectrical cross section of the soil layers. The first layer of figure 5 represents the top soil and has a resistivity of $46.28 \mathrm{~m}$ and depth of $1.96 \mathrm{~m}$. The maximum resistivity value of 296.10 m which indicated the presence of aquifer was got at the fourth layer with a depth of $52.32 \mathrm{~m}$ and thickness of $39.69 \mathrm{~m}$. The fifth layer whose depth could not be ascertained has a resistivity value of $186.20 \mathrm{~m}$. The first layer of figure 6 represents the top soil has a resistivity of $47.10 \mathrm{~m}$ and depth of $1.96 \mathrm{~m}$. The maximum resistivity value of $248.60 \mathrm{~m}$ which indicate the presence of aquifer was got at the fourth layer with a depth of $35.28 \mathrm{~m}$ and thickness of $24.48 \mathrm{~m}$. The fifth layer whose depth could not be ascertained has a resistivity value of $148.30 \mathrm{~m}$.

Comparing figures 5 and 6 show that although the two (2) locations have five layers respectively but the depth of aquifer differ significantly with the aquifer depth at first location at $52.32 \mathrm{~m}$ and that of the second location at $35.28 \mathrm{~m}$. This clearly shows that the second location which is closer to the oil spill site and with shallow aquifer will be more contaminated than the first location.

Table 1: Field and Calculated data

\begin{tabular}{|c|c|c|c|c|c|c|c|c|c|}
\hline \multirow[t]{2}{*}{ No } & \multirow{2}{*}{$\begin{array}{l}\mathrm{AB} / 2 \\
(\mathrm{M})\end{array}$} & \multirow{2}{*}{$\begin{array}{l}\text { MN/2 } \\
(\mathrm{M})\end{array}$} & \multirow[t]{2}{*}{$\mathrm{K}$} & \multicolumn{3}{|c|}{ Site 1} & \multicolumn{3}{|c|}{ Site 2} \\
\hline & & & & $\mathrm{R}(\mathrm{)}$ & 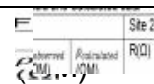 & 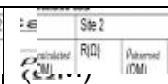 & $\mathrm{R}(\mathrm{)})$ & - & $\bar{z}$ \\
\hline 1. & 1.00 & 0.30 & 10.24 & 0.54 & 5.53 & 2.17 & 0.72 & 7.36 & 1.23 \\
\hline 2. & 2.00 & 0.30 & 41.65 & 0.15 & 6.25 & 5.20 & 0.63 & 26.23 & 4.23 \\
\hline 3. & 3.00 & 0.30 & 94.01 & 0.27 & 25.38 & 8.44 & 0.54 & 50.76 & 8.24 \\
\hline 4. & 4.00 & 0.30 & 167.32 & 0.70 & 117.12 & 12.10 & 0.62 & 103.72 & 13.90 \\
\hline 5. & 4.00 & 0.50 & 60.08 & 0.81 & 48.66 & 12.10 & 0.93 & 93.09 & 13.90 \\
\hline 6. & 5.00 & 0.50 & 94.01 & 0.59 & 55.47 & 17.00 & 0.62 & 97.09 & 21.76 \\
\hline 7. & 6.00 & 0.50 & 135.48 & 0.48 & 65.03 & 21.70 & 0.67 & 151.28 & 29.35 \\
\hline 8. & 7.00 & 0.50 & 184.49 & 0.71 & 130.99 & 26.40 & 0.45 & 138.33 & 37.28 \\
\hline 9. & 8.00 & 0.50 & 241.04 & 0.48 & 115.70 & 32.80 & 0.35 & 140.59 & 48.77 \\
\hline 10. & 8.00 & 1.00 & 60.08 & 0.48 & 28.84 & 32.80 & 0.38 & 76.08 & 48.77 \\
\hline 11. & 10.00 & 1.00 & 94.01 & 0.37 & 34.78 & 43.90 & 0.26 & 81.46 & 70.71 \\
\hline 12. & 15.00 & 1.00 & 211.82 & 0.52 & 110.15 & 73.00 & 0.03 & 21.18 & 128.10 \\
\hline 13. & 15.00 & 1.50 & 94.01 & 0.60 & 56.41 & 73.00 & 0.14 & 65.80 & 128.10 \\
\hline 14. & 20.00 & 1.50 & 167.32 & 0.47 & 78.64 & 97.60 & 0.32 & 267.68 & 195.10 \\
\hline 15. & 25.00 & 1.50 & 261.56 & 0.80 & 209.25 & 124.00 & 0.28 & 366.18 & 267.00 \\
\hline 16. & 30.00 & 1.50 & 376.76 & 0.85 & 320.25 & 151.300 & 0.13 & 244.88 & 329.20 \\
\hline 17. & 30.00 & 2.50 & 135.48 & 0.83 & 112.45 & 151.00 & 0.11 & 124.19 & 329.20 \\
\hline 18. & 40.00 & 2.50 & 241.04 & 0.63 & 151.86 & 197.00 & 0.37 & 743.18 & 380.80 \\
\hline 19. & 50.00 & 2.50 & 376.76 & 0.55 & 207.22 & 257.00 & 0.47 & 1475.61 & 419.20 \\
\hline 20. & 60.00 & 2.50 & 542.63 & 1.74 & 944.18 & 305.00 & 0.65 & 2939.23 & 432.90 \\
\hline 21. & 60.00 & 5.00 & 135.48 & 1.68 & 227.61 & 305.00 & 0.56 & 1264.48 & 432.90 \\
\hline 22. & 70.00 & 5.00 & 184.49 & 0.55 & 101.47 & 328 & 0.31 & 953.18 & 420.90 \\
\hline 23 & 80.00 & 5.00 & 241.04 & 0.34 & 81.95 & 336.00 & 0.37 & 1486.40 & 393.00 \\
\hline 24. & 80.00 & 7.50 & 107.00 & 0.37 & 39.59 & 336.00 & 0.47 & 1257.20 & 393.00 \\
\hline 25. & 100.00 & 7.50 & 167.32 & 0.36 & 60.24 & 328.00 & 0.34 & 1422.15 & 329.00 \\
\hline 26. & 100.00 & 10.00 & 94.01 & 0.41 & 38.54 & 328.00 & 0.37 & 1159.46 & 324.00 \\
\hline 27. & 150.00 & 10.00 & 211.82 & 0.63 & 133.45 & 251.00 & & & \\
\hline
\end{tabular}




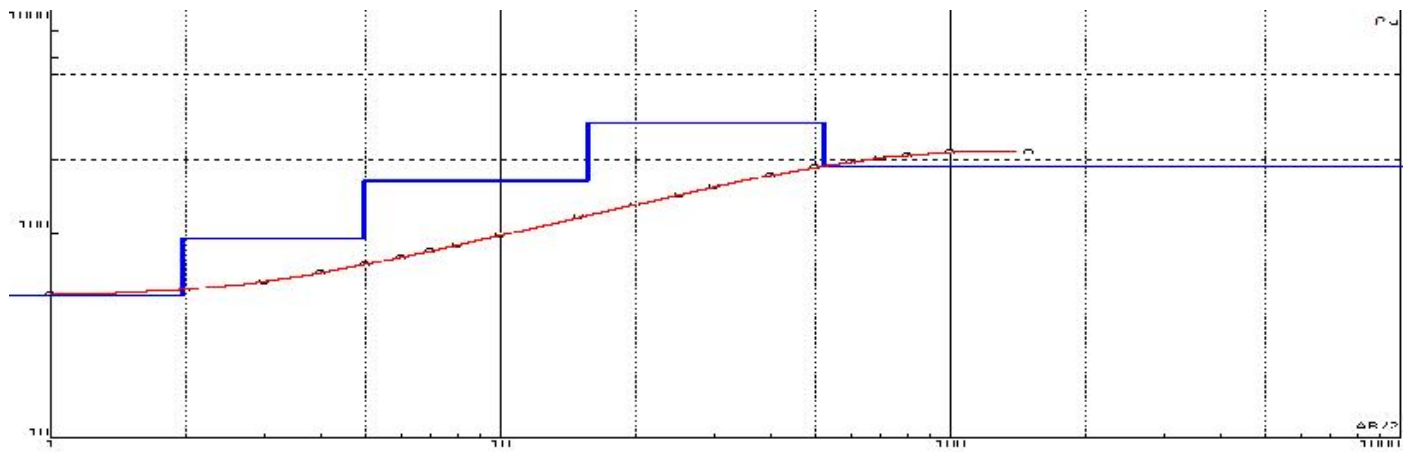

Figure 5: Interpreted VES curve model one

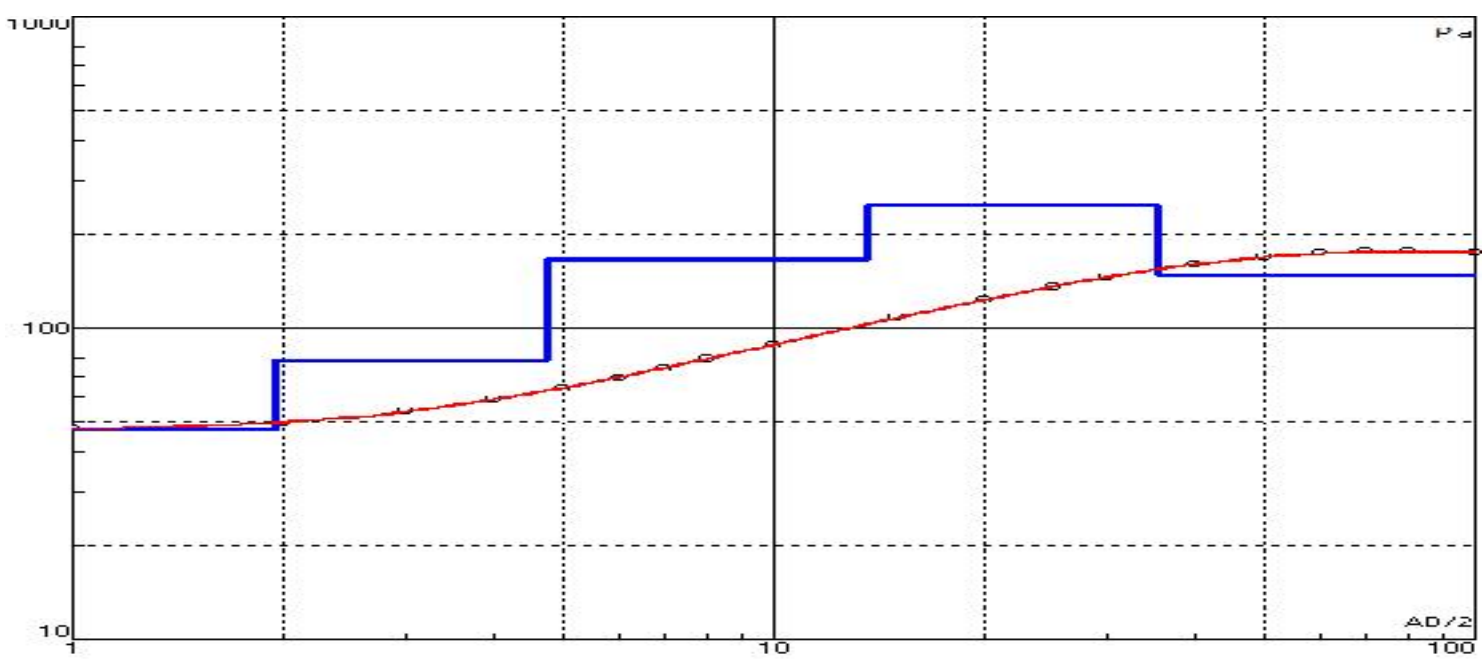

Figure 6: Interpreted VES curve model two

Table 2: The layer parameter of the Geoelectric sections of field data

\begin{tabular}{|c|c|c|c|c|c|c|}
\hline \multirow{2}{*}{$\begin{array}{l}\text { Layer } \\
\text { number }\end{array}$} & \multicolumn{3}{|l|}{ Site 1} & \multicolumn{3}{|l|}{ Site 2} \\
\hline & $\begin{array}{l}\text { Resistivity } \\
\left(\begin{array}{l}\text { m) }\end{array}\right.\end{array}$ & $\begin{array}{l}\text { Depth } \\
\text { (m) }\end{array}$ & $\begin{array}{l}\text { Thickness } \\
\text { (m) }\end{array}$ & $\begin{array}{l}\text { Resistivity } \\
\left(\begin{array}{l}\text { m) }\end{array}\right.\end{array}$ & Depth (m) & $\begin{array}{l}\text { Thickness } \\
\text { (m) }\end{array}$ \\
\hline 1 & 46.30 & 2.00 & 1.96 & 47.10 & 2.00 & 2.00 \\
\hline 2 & 85.40 & 5.00 & 3.00 & 79.00 & 4.80 & 2.80 \\
\hline 3 & 159.00 & 15.60 & 12.60 & 166.20 & 13.60 & 10.80 \\
\hline 4 & 296.10 & 52.30 & 39.70 & 248.60 & 35.30 & 24.50 \\
\hline 5 & 186.20 & - & - & 148.30 & & \\
\hline
\end{tabular}




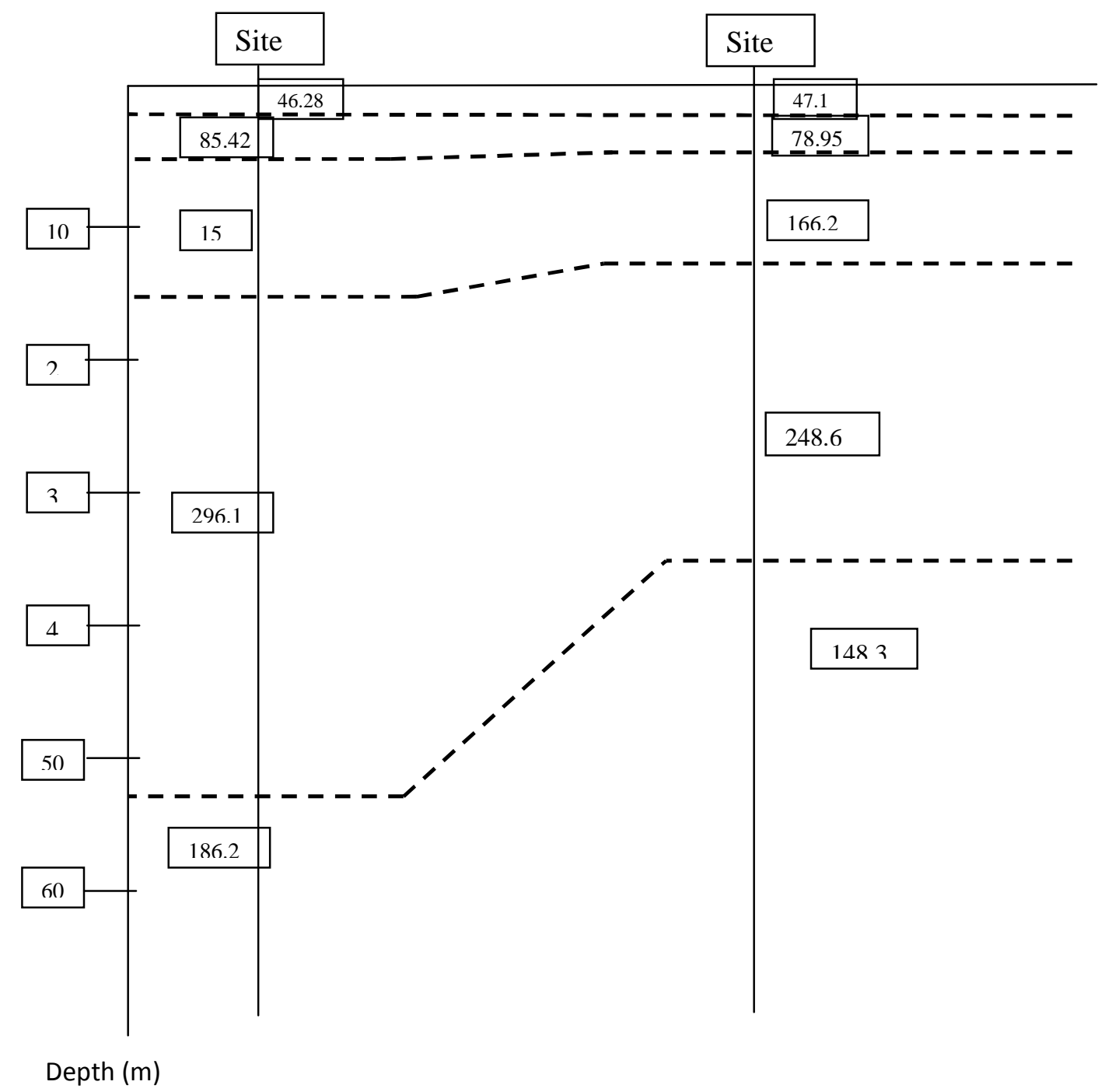

Figure 7: Hydrogeoelectrical cross section

\section{CONCLUSION}

The result of the electrical resistivity investigation of Bodo community using vertical electrical sounding survey shows that the study area is characterized by shallow aquifer ranging from depth of $30 \mathrm{~m}$ to about $60 \mathrm{~m}$. The zone of high resistivity indicates the presence of aquifer that is zone of resistivity value of $296.10 \mathrm{~m}$ in model one and 248.60

$\mathrm{m}$ in model two. The thickness of the various layer in the different location differs significantly with location one having average thickness of 14.32 meters while location two has an average thickness of 10.00 meters.

It also shows that the oil spill will overtime have adverse effect on the groundwater closer to the oil spill site. Also, continuous overlook of the oil spillage will overtime spread across the entire region if immediate response or clearing of the spilled oil both on the land and in the rivers since river water also serves as a source of aquifer recharge.

\section{REFERENCES}

Chambers, J. C., Kuras, O., Meldrum, P. I., Ogilvy, R. D and Hollands, J., 2006. Electrical Resistivity Tomography. Applied to Geologic, Hydrogeologic, and Engineering Investigations at a Formal Waste-Disposal Site. Geophysics 71 (6), B231-B239.

Dobrine, M. B., 1960. Introduction to Geophysical Prospecting. ( $2^{\text {nd }}$ edition), Mc Grawhill Book Co. Inc., 446p. New York.

Okolie E. C., Egbai J. C and Oseji J. O., 2008. Comparative investigation of formation strata and groundwater distributions in Orerokpe and Ovu Delta State using Schlumberger array Nigerian J. Sci. Environ., 7: 91-98. 
Okolie E. C., Atakpo E and Okpikoro F. E., 2010. Application of linear schlumberger configuration in delineation of formation strata and groundwater distribution in Ifon Ondo State, Nigeria. International Journal of the Physical Sciences, 5, (6): 642-650.

Available online

at

http://www.academicjournals.org/lJPS ISSN 1992 - 1950.

Reynolds, J. M., 1997. An Introduction To Applied And Environmental Geophysics. John Wiley And Sons Ltd, 796 pp, First edition, Chichester.

Robain, H., Descloitres, M., Ritz, M and Yene Atangana Q., 1996. A Multiscale Electrical Survey of A Lateritic Soil System In The Rain Forest Of Cameroon: Journal of Applied Geophysics, 3, 237-253.
Samouelian Anatja, Isabelle Cousin, Akin Tabbagh, Ary

Bruand and Guy Richard., 2005. Electrical Resistivity Survey in Soil Science, a Review of Soil and Tillage Research, Elsevier p.2, 173-193.

Storz, H., Storz, W and Jacobs, F., 2000. Electrical Resistivity Temography To Investigate Geologic Structures Of The Earth's Upper Crust. Geophys Prospect 48: 455-471.

UNEP., 2011. United Nations Environmental Progranme Report. Environmental Assessment of Ogoniland 